\title{
The utilization of Social Media in marketing the Lebanese Higher Education institutions
}

\author{
Fadia Ismail $^{1 *}$ \\ ${ }^{1}$ Varna Free University, Yanko Slavchev 84,Chaika Resort, 9007 Varna, Bulgaria
}

\begin{abstract}
In today's competitive environment, it is significant to develop a strong community that retains existing customers and attracts new ones. Higher education institutions in Lebanon, given the pandemic, are shifting to online platforms to market their services. The article explains how HEIs in Lebanon use social media as a way of engaging and communicating with stakeholders. Using a questionnaire targeting the marketing department of the Lebanese HEIs, managerial and marketing implications will be presented to explain the promotional implications of using social media and its challenges. The findings showed that most Lebanese higher educational institutions are utilizing social media strategies when planning their marketing efforts, due to the fear of losing control of its reputation and the limited budget allocated for these efforts. Moreover, they have a limited understanding of its value and its implications and, thus, use it solely for communication purposes with their current and potential students, rather than showing what they do as research centers.
\end{abstract}

\section{Introduction}

Many commercial organizations nowadays are applying social media marketing and advertising techniques in order to achieve their goals. Social media are Internet-based applications built on the foundations of Web 2.0 that allow creating and exchanging usergenerated content and interacting through discussions.[1]. Thus, it becomes natural for higher educational institutions (HEIs) to explore such opportunities and techniques in order to engage with potential students, their alumni and all their stakeholders [2].

Moreover, social media has a vital role in connecting people and developing relations and provides a great chance for providing a better customer service through collecting input, answering queries and listening to the feedback unlike the traditional media available. Potential university and college students are more likely to be reached by and supportive to organizations that utilize these tools to attract them and engage with them due to social media's unprecedented growth and diversity, especially when looking at these tools from the whole organization's view and not merely a marketing perspective. HEI can also make use of the emergence of virtual communities that are created over such platforms in order to reach their targeted market [3].

\footnotetext{
* Corresponding author: fadiah192@gmail.com
} 
These days, the importance doesn't lie only in building an inclusive and solid community, yet also includes the necessity of engagement with the alumni and other members of the organization in order to recruit prospective applicants [4]. In addition to the highly competitive environment where higher educational institutions are operating in, adopting modern communication channels, specifically social media, is justifiable [5]. Thus, this study targets the Lebanese HEIs to investigate how social media tools are being used in marketing and communication with their stakeholders. So, a quantitative research was conducted based on a sample of 30 HEIs in Lebanon.

\section{Social Media and Higher Education Institutions}

In reference to previous social media research, HEIs are getting more skilled at using the information from various social media networks that help enhance what is being provided and the reputation of the organization as well as help sustain relationships with customers $[6,7]$. The current higher education environment is currently driven by a digital native generation who perceive Internet to be a normal part of their everyday lives $[8,9]$. So, they find it easier to utilize social media to stay updated with universities' new activities and programs $[10,11]$.

As a result, universities can approach this generation by using social media with more creativity, as these "digital natives" emphasize mostly the authenticity of perspectives as well as a two-way communication when it comes to choosing a higher educational program or institution. With the variety of social media platforms available, higher educational institutions may utilize platforms like Facebook, YouTube, Instagram, Pinterest, Snapchat, Twitter, and LinkedIn, of course based on the set goals and targeted audience [12].

\section{Social Media and Students Enrolment}

In order to make student enrolment processes in the higher education sector more responsive and personalized, social media are considered to be of high significance in such situations due to the highly competitive environment [13]. The majority of higher education admission researchers claim that candidates will have a better overall experience if it was customized when reaching their potential higher education institutions, especially the first time [14]. Thus, social media is more likely to reach potential applicants who belong to the generation of "digital natives" as they include those that are highly knowledgeable of technology and social media specifically $[15,16]$.

In addition, the choice of university or college ad programs to be enrolled in doesn't rely merely on the educational offer, yet is inclusive of the value that is being offered. This value can be easily and confidently communicated through a social media channel, as the prospects can gain an informal view of their future university or program that is not found on the traditional university's website [17]. In sum, prospective university applicants require credibility as well as customized communication that will help them identify their best-fitted university, and with the help of social media channels and tools, HEIs are using it to provide their target market with an added informal source of information [18].

\section{Social Media in the Process of Studying}

When people utilize social media networks during their daily lives, they tend to perceive a huge difference in the way they use them for learning purposes or as sources of educational information [19]. 
As prospects are used to sharing ideas and inquiries in addition to reviews and solutions through these platforms, HEIs found it necessary to target and communicate with them over social media, being the most natural way of communication these days [20]. However, social media can be used for more than just attracting new students, but rather engaging with the current students of the university and pushing them to participate in university life activities. By shedding importance on the current students enrolled, their achievements and activities can help the university in achieving its goals as well as providing potential applicants with an overall view of the culture and academic life. Thus, it is significant to carry out this study to investigate these effects in the Lebanese higher education sector, focusing on how and why they adopt social media channels and tools in marketing.

\section{Methodology}

The study was conducted on a group of 38 higher education institutions in Lebanon, using an online questionnaire and individual invites sent to marketing/public relations departments of these institutions - and people serving these departments - and was completed by 32 people. The findings were compiled using 30 fully completed questionnaires, resulting in a high response rate of nearly 78 percent.

The questionnaire was created so that respondents could rate their responses based on their personal preferences. A tool known as the relative importance index (RII) method was used to analyze these results. It is used to assess the relative relevance of attitudes and barriers to using social media. The five-point Likert scale ranged from 1 to 5 is adopted and transformed to relative importance indices (RII) for each factor as follows, where $\mathrm{W}$ is the weighting given to each factor by the respondents (ranging from 1 to 5), A is the highest weight (i.e., 5 in this case), and $\mathrm{N}$ is the total number of respondents. The higher the value of RII, the more important the factor was (35). Values of Relative Importance Index of each question were analyzed based on the below table.

$$
R I I=\sum W /(A \times N)
$$

Table 1. Relative Importance Index Ranking - Source: Adopted from Livesey [21].

\begin{tabular}{|c|c|c|}
\hline RII Values & \multicolumn{2}{|c|}{ Importance Level } \\
\hline $0.8 \leq \mathrm{RII} \leq 1$ & High & $\mathrm{H}$ \\
\hline $0.6 \leq \mathrm{RII}<0.8$ & Medium-High & $\mathrm{M}-\mathrm{H}$ \\
\hline $0.4 \leq \mathrm{RII}<0.6$ & Medium & $\mathrm{M}$ \\
\hline $0.2 \leq \mathrm{RII}<0.4$ & Low-Medium & $\mathrm{L}-\mathrm{M}$ \\
\hline $0 \leq \mathrm{RII}<0.2$ & Low & $\mathrm{L}$ \\
\hline
\end{tabular}

\section{Results and Discussions}

Results showed that the vast majority of HEIs (30 out of 38 surveyed) have been taking advantage of social media for at least three years, with 20 of them $(40 \%$ of the whole surveyed sample) using social media for over six years. Only three of them stated to have been using social media for just two years.

The way social media are managed at Lebanese HEIs differs greatly in terms of: the time devoted to do it, the number of people engaged in the process or the support of external entities. $34 \%$ of the responding HEIs devote more than ten hours per week to use social media, $26 \%$ speak of six-ten hours, and $28 \%$ of one-five hours per week. 
In $14 \%$ of cases, social media are managed/handled by more than six persons, in $44 \%$ of the respondents there are two-three persons involved in the process, and $10 \%$ have four-five such persons. $26 \%$ of the surveyed HEIs (13 out of 50 ) have only one person to manage their social media platforms. Lebanese HEIs use social media agency services very rarely. $74 \%$ of those surveyed do not work with any external entities, $18 \%$ of them speak of such collaboration as small (operational support), and only $8 \%$ refer to it as moderate or extensive (four such responses).

Although, social media is considered a very important channel of advertising communication (the purchase and publishing of adverts in social media), $68 \%$ of the respondents said that their budget for social media advertising activity amounted to $0-20 \%$ of the total promotion budget, and only $6 \%$ of them allocate $21-40 \%$ of their overall budget to such a type of advertising. Interestingly enough, $22 \%$ of the respondents could not specify the exact or even approximate value of their expenses on social media advertising. Thus, it seems that social media is still not seen as an important tool for communication worth investing in, despite previous research concluded that social media are supportive in the enrolment process.

At the same time, almost half of the respondents (46\%) expect these budgets to grow in the next one to three years, and $22 \%$ of them think they will stay at the same level. The uncertainty related to treating social media as means of advertising is proven by the fact that even $26 \%$ of the respondents have chosen 'hard to say' as their answer. Lebanese HEIs do not regulate broadly defined activity of their employees in social media. $62 \%$ of the respondents declared that their institution does not have any code to determine the way their employees should use social media (a so-called social media policy). In addition to that, $6 \%$ of them claimed that even though they have developed such principles, they are not known or applied in practice. Only $12 \%$ of cases (6 HEIs) have social media policies that are not only formalized but also implemented. Which means that still social media utilization is not a professionalized action, but rather an addition to traditional marketing tools.

\subsection{Respondents' Attitudes to Selected Aspects of Social Media}

Respondents of this study were asked about their opinions regarding social media usage of the institutions they represent. By applying the Relative Importance Index technique, the data achieved is presented below in Table 2. It is seen that most academics are satisfied with their institution's activity and operation on social media as it holds the highest-ranking index of 0.77 , representing a medium to high importance for the respondents. Similarly, all the other questions asked ranked a medium to high importance level, with indices greater than 0.6 with the lowest being 0.65 , which refers to the activity of the provost and chairman of the institutions on social media, showing the least importance.

However, the issue regarding the attitude of HEI authorities in Lebanon regarding social media certainly necessitates a greater in-depth analysis and further research. This is due to the fact the ranking of the importance of social media perceived by authorities of the institutions (question 7) exceeds that of them having an actual social media presence (question 14) and their participation in social media activities and events (question 8). Moreover, it is said that the decision-makers, i.e., authorities of the HEI, utilize social media insights although they do not participate and do not have a social media presence themselves. Therefore, some of the responses were contradicting each other when ranked. 
Table 2. Ranking Attitudes of Respondents Regarding the Social Media Activity of Their Institutions.

\begin{tabular}{|l|c|c|c|c|}
\hline \multicolumn{1}{|c|}{ Question } & $\begin{array}{c}\text { Question } \\
\text { Number }\end{array}$ & Rank & RII & RII Level \\
\hline $\begin{array}{l}\text { I'm pleased with the social media operation of my } \\
\text { educational institution. }\end{array}$ & 2 & 1 & .77 & $\begin{array}{c}\text { Medium - } \\
\text { High }\end{array}$ \\
\hline $\begin{array}{l}\text { On a regular basis, we examine the social media } \\
\text { usage of other educational institutions. }\end{array}$ & 4 & 2 & .75 & $\begin{array}{c}\text { Medium - } \\
\text { High }\end{array}$ \\
\hline $\begin{array}{l}\text { The social media budget is determined by the results } \\
\text { obtained in previous periods of social media } \\
\text { operation. }\end{array}$ & 3 & 3 & .75 & $\begin{array}{c}\text { Medium - } \\
\text { High }\end{array}$ \\
\hline $\begin{array}{l}\text { In my educational institution, social media is an } \\
\text { integral part of marketing. }\end{array}$ & 1 & 4 & .75 & $\begin{array}{c}\text { Medium - } \\
\text { High }\end{array}$ \\
\hline $\begin{array}{l}\text { The education institution's decision-makers use the } \\
\text { insights gathered from social media. }\end{array}$ & 5 & 5 & .74 & $\begin{array}{c}\text { Medium - } \\
\text { High }\end{array}$ \\
\hline $\begin{array}{l}\text { In regards to social media, the educational institution } \\
\text { is quite well. }\end{array}$ & 9 & 6 & .73 & $\begin{array}{c}\text { Medium - } \\
\text { High }\end{array}$ \\
\hline $\begin{array}{l}\text { In social media, we monitor the return on } \\
\text { investment. }\end{array}$ & 6 & 7 & .73 & $\begin{array}{c}\text { Medium - } \\
\text { High }\end{array}$ \\
\hline $\begin{array}{l}\text { The social media activities of the educational } \\
\text { institution have an impact on enrolment at the } \\
\text { institution of higher education. }\end{array}$ & 10 & 8 & .73 & $\begin{array}{c}\text { Medium - } \\
\text { High }\end{array}$ \\
\hline $\begin{array}{l}\text { The costs of marketing activities have been reduced } \\
\text { as a result of our social media activities. }\end{array}$ & 11 & 9 & .72 & $\begin{array}{c}\text { Medium - } \\
\text { High }\end{array}$ \\
\hline $\begin{array}{l}\text { The administration of the educational institution } \\
\text { recognizes the importance of social media in the } \\
\text { educational institution. }\end{array}$ & 8 & 10 & .71 & $\begin{array}{c}\text { Medium - } \\
\text { High }\end{array}$ \\
\hline $\begin{array}{l}\text { The social media activities of the educational } \\
\text { institution are focused on a well-thought-out plan. }\end{array}$ & 12 & 11 & .70 & $\begin{array}{c}\text { Medium - } \\
\text { High }\end{array}$ \\
\hline $\begin{array}{l}\text { The authorities of educational institutions participate } \\
\text { in social media events. }\end{array}$ & 7 & 12 & .70 & $\begin{array}{c}\text { Medium - } \\
\text { High }\end{array}$ \\
\hline $\begin{array}{l}\text { We engage in events that motivate and inspire our } \\
\text { students. Alumni to help us develop and support our } \\
\text { social media brand. }\end{array}$ & 13 & 13 & .67 & $\begin{array}{c}\text { Medium - } \\
\text { High }\end{array}$ \\
\hline $\begin{array}{l}\text { The provost and chairman of the board have social } \\
\text { media accounts. }\end{array}$ & 14 & 14 & .65 & $\begin{array}{c}\text { Medium - } \\
\text { High }\end{array}$ \\
\hline
\end{tabular}

\subsection{Barriers to Using Social Media at Lebanese Higher Education Institutions}

This study also aimed at identifying the main barriers to using social media at HEIs in Lebanon. Respondents rated many potential factors that affect the application of social media networks. As seen in the table below (Table 3), the 3 highest-ranked factors include the fear of losing control of the HEI's reputation with a relative index of 0.81 , referring to a high importance, followed by the poor coordination of practices undertaken through social media, with a relative index of 0.75 , and finally the lack of material availability, with an index of 0.74 . On the other hand, the factor that has the lowest index, of 0.6 , refers to the absence of academic staff's understanding of social media importance when establishing its position in the market. 
Table 3. Ranking Respondents' Answers to the Question: What are the barriers at Your Educational Institution when using Social Media? (Choose Max. 3 Most Important Ones).

\begin{tabular}{|l|c|c|c|c|}
\hline \multicolumn{1}{|c|}{ Question } & $\begin{array}{c}\text { Question } \\
\text { Number }\end{array}$ & Rank & RII & RII Level \\
\hline $\begin{array}{l}\text { Fear of losing control of the reputation of the educational } \\
\text { institution. }\end{array}$ & 11 & 1 & .81 & High \\
\hline $\begin{array}{l}\text { The practices undertaken through social media are not } \\
\text { well coordinated. }\end{array}$ & 7 & 2 & .75 & $\begin{array}{c}\text { Medium - } \\
\text { High }\end{array}$ \\
\hline There is no material available. & 9 & 3 & .74 & $\begin{array}{c}\text { Medium - } \\
\text { High }\end{array}$ \\
\hline $\begin{array}{l}\text { Absence of understanding of the importance of social } \\
\text { media in establishing the education institution's market } \\
\text { position among the education institution's administrative } \\
\text { staff. }\end{array}$ & 2 & 4 & .73 & $\begin{array}{c}\text { Medium - } \\
\text { High }\end{array}$ \\
\hline $\begin{array}{l}\text { Change resistance - slowdown implementation of specific } \\
\text { tools and solutions }\end{array}$ & 5 & 5 & .70 & $\begin{array}{c}\text { Medium - } \\
\text { High }\end{array}$ \\
\hline Fear of feedback - and the need to respond to it & 8 & 6 & .69 & $\begin{array}{c}\text { Medium - } \\
\text { High }\end{array}$ \\
\hline $\begin{array}{l}\text { Despite the potential of engaging professionals, there are } \\
\text { no human resources. }\end{array}$ & 10 & 7 & .67 & $\begin{array}{c}\text { Medium - } \\
\text { High }\end{array}$ \\
\hline There is no money set aside to hire new experts. & 3 & 8 & .67 & $\begin{array}{c}\text { Medium - } \\
\text { High }\end{array}$ \\
\hline $\begin{array}{l}\text { The administration's lack of willingness to develop this } \\
\text { mode of communication }\end{array}$ & 6 & 9 & .67 & $\begin{array}{c}\text { Medium - } \\
\text { High }\end{array}$ \\
\hline $\begin{array}{l}\text { Lack of understanding of how to build and apply new } \\
\text { tools and practices }\end{array}$ & 4 & 10 & .61 & $\begin{array}{c}\text { Medium - } \\
\text { High }\end{array}$ \\
\hline $\begin{array}{l}\text { Academic workers at the education institution have a poor } \\
\text { understanding of the importance of social media in } \\
\text { establishing the institution's market place. }\end{array}$ & 1 & 11 & .60 & $\begin{array}{c}\text { Medium } \\
\text { Medium }\end{array}$ \\
\hline
\end{tabular}

\section{Conclusion}

Today, we live in a dynamic, fast-paced world where everyone has a limited time pushing us to see the undeniable significance of social media channels and tools and their benefits to businesses and our lives [22, 23]. When focusing on social media benefits in the higher educational sector in Lebanon, we can see that social media is limited to attracting prospects to the university and, unfortunately, lacks focus on the academic achievements of the university as research and academic centers. Moreover, the responses show that higher educational institutions are in fear of losing the university's reputation due to the virality of social media channels, which is considered as the greatest obstacle facing them in adopting more advanced social media techniques. So, it is clear that the Lebanese HEIs do not consider social media as a major advertising communication channel yet.

In addition, a main barrier to a more inclusive social media adoption is the lack of a clear understanding when it comes to the significance of these media in brand building across the organization. Also, the limited financial resources and the lack of expertise in the matter hinder the ability of such comprehensive and advanced social media application and adoption.

Regarding their attitudes towards social media channels, responses showed an ambiguous view by respondents as they emphasized its importance in marketing of their organizations, yet they seem to be satisfied with the activities being adopted and implemented. 
Therefore, we can say that higher educational institutions in Lebanon can further enhance their understanding of social media marketing that will help them in maintaining relationships with their current students and stakeholders, build new relationships with potential applicants, and stay knowledgeable of what their competitors are up to.

Similar to all studies, this one has its limitations that include a small sample with different backgrounds and marketing positions within the HEI, that would've influenced the responses given on the survey. This makes it necessary to further investigate this topic with a more inclusive and specified sample in order to grasp the development of and utilization of social media strategies and maybe be able to compare the results obtained from surveys filled by students and with those of the academic staff.

\section{References}

1. A.M. Kaplan, Social Media, the Digital Revolution, and the Business of Media, International Journal on Media Management, 197-199 (2015)

2. J. Wang, M. Yang, P. Maresova, Sustainable Development at Higher Education in China: A Comparative Study of Students' Perceptionin Public and Private Universities, Sustainability (2020)

3. E. McDade-Montez, Social Media, Traditional Media: Really Different? Or Really the Same?, https://www.etr.org/blog/social-media-traditional-media-really-different-orreally-the-same/ (2018)

4. R. Nevzat, Y. Amca, C. Tanova, H. Amca, Role of Social Media Community in Strengthening Trust and Loyalty for a University. Eastern Mediterranean University (2016)

5. M. J. Zickar, T.H. Ron, C. Arnold, Using Facebook Pages to Connect with Students, Faculty, Alumni, and Friends: An Empirical Analysis, Teaching of Psychology, 358362 (2018)

6. S. Grajek, How Colleges and Universities are Driving to Digital Transformation Today, EduCause, https://er.educause.edu/articles/2020/1/how-colleges-anduniversities-are-driving-to-digital-transformation-today. (2020)

7. A. Rof, A. Bikfalci, P. Marques, Digital Transformation for Business Model Innovation in Higher Education: Overcoming, Sustainability, https://www.mdpi.com/journal/sustainability (2020)

8. C. Jones, B. Shao, The Net Generation and Digital Natives: Implications for Higher Education, Higher Education Academy, York, 1-53 (2011)

9. F. Lupiáñez-Villanueva, G. Gaskell, P. Tornese, J. Vila, Y. Gomez, A. Allen, G. Veltri, C. Codagnone, Behavioural Study on the Transparency of Online, Consumers, Health Agricultue and Food Executive Agency, Brussels (2015)

10. S. Segaren, The Important Role of Social Media in Higher Education. Study International (2019)

11. P. Maresova, J. Hruska, K. Kuca, Social Media University Branding, Education Sciences, 2-14 (2020)

12. N. N. Paladan, Higher Education Institutions Embracing Digital \& Social Media Marketing: A Case of Top 25 Universities in Asia \& Africa, SSRN Electronic Journal, 159-167 (2018)

13. G. Zachos, E. Paraskevopoulou-Kollia, I. Anagnostopoulos, Social Media Use in Higher Education: A Review, Education Sciences (2018)

14. C. Huebner, How Students Perceive Social Media Ads and What That Means for Enrolment Management Marketers, INSIDE HIGHER ED (2020) 
15. T. Correa, Digital Skills and Social Media Use: How Internet Skills Are Related to Different Types of Facebook Use Among 'Digital Natives', Information, Communication and Society (2015)

16. K. Sehl, Social Media in Higher Education: 8 Essential Tips, Hootsuite, https://blog.hootsuite.com/social-media-in-higher-education/ (2020)

17. K. Sutherland, C. Davis, U. Terton, I. Visser, University Student Social Media Use and Its Influence on Offline Engagement in Higher Educational Communities, Student Success, 13-24 (2018)

18. D. Bok, Improving the Quality of Education, Inside Higher Ed, https://www.insidehighered.com/views/2017/09/21/how-improve-quality-highereducation-essay (2017)

19. R. Fkihi, S. El Faizi, Investigating the Role of Social Networks in Enhancing Students' Learning Experience: Facebook as a Case Study, International Conference e-Learning, 151-155 (2018)

20. F. Froment, A. Javier, G. Gonzalez, M. R. Bohorquez, The Use of Social Networks as a Communication Tool between Teachers and Students: A Literature Review, The Turkish Online Journal of Educational Technology, 126-144 (2017)

21. P. Livesey, Insights of Project Managers into the Problems in Project Management, Construction Economics and Building (2016)

22. A. Kaul, V. Chaudhri, D. Cherian, K. Freberg, S. Mishra, R. Kumar, J. Pridmore, S. Y. Lee, N. Rana, U. Majmudar, C. E. Carroll, Social Media: The New Mantra for Managing Reputation, The Journal of Decision Makers, 455-491 (2015)

23. A. Kisiolek, O. Karyy, L. Halkiv, The Utilization of Internet Marketing Communication Tools by Higher Education Institutions, International Journal of Education Management (2021) 